\title{
Chromosomal imbalances are uncommon in chagasic megaesophagus
}

\author{
Marilanda F Bellini ${ }^{1,2}$, Antonio J Manzato ${ }^{3}$, Ana E Silva ${ }^{1 *}$, Marileila Varella-Garcia ${ }^{2}$
}

\begin{abstract}
Background: Chagas' disease is a human tropical parasitic illness and a subset of the chronic patients develop megaesophagus or megacolon. The esophagus dilation is known as chagasic megaesophagus (CM) and one of the severe late consequences of CM is the increased risk for esophageal carcinoma (ESCC). Based on the association between CM and ESCC, we investigated whether genes frequently showing unbalanced copy numbers in ESCC were altered in $\mathrm{CM}$ by fluorescence in situ (FISH) technology.

Methods: A total of 50 formalin-fixed, paraffin-embedded esophageal mucosa specimens (40 from Chagas megaesophagus-CM, and 10 normal esophageal mucosa-NM) were analyzed. DNA FISH probes were tested for FHIT, TP63, PIK3CA, EGFR, FGFR1, MYC, CDKN2A, YES1 and NCOA3 genes, and centromeric sequences from chromosomes 3, 7 and 9.

Results: No differences between superficial and basal layers of the epithelial mucosa were found, except for loss of copy number of EGFR in the esophageal basal layer of CM group. Mean copy number of CDKN2A and CEP9 and frequency of nuclei with loss of PIK3CA were significantly different in the CM group compared with normal mucosa and marginal levels of deletions in TP63, FHIT, PIK3CA, EGFR, CDKN2A, YES and gains at PIK3CA, TP63, FGFR1, MYC, CDNK2A and NCOA3 were detected in few CM cases, mainly with dilation grades III and IV. All changes occurred at very low levels.
\end{abstract}

Conclusions: Genomic imbalances common in esophageal carcinomas are not present in chagasic megaesophagus suggesting that these features will not be effective markers for risk assessment of ESCC in patients with chagasic megaesophagus.

\section{Background}

Chagas' disease is a human tropical parasitic disease which occurs in the Americas, particularly in South America. It affects 16 to 18 million people in tropical and subtropical countries of Latin America [1]; in Brazil, the number of cases has reached 6 million [2]. During the chronic phase, 6 to $7 \%$ of chagasic patients develop mega syndromes represented by muscular hypertrophy and dilation of the esophagus or colon, in consequence of destruction of the myoenteric and submucous plexus by the protozoan Trypanosoma cruzi[3]. The digestive forms, megaesophagus or megacolon may be observed in advanced stages of the disease [3].

Megaesophagus is consequence of achalasia characterized by the destruction or lack of intramural nerve

\footnotetext{
* Correspondence: anabete@ibilce.unesp.br

'UNESP, São Paulo State University, Department of Biology, Campus São José do Rio Preto, SP, Brazil
}

C) Biomed Central

C 2010 Bellini et al; licensee BioMed Central Ltd. This is an Open Access article distributed under the terms of the Creative Commons Attribution License (http://creativecommons.org/licenses/by/2.0), which permits unrestricted use, distribution, and reproduction in any medium, provided the original work is properly cited. lack of openness of the lower esophageal sphincter in response to swallowing. In consequence, food retention or esophageal stasis occurs, leading to the appearance of chronic esophagitis, acanthosis, paraceratose and leukoplakia, possibly pre-cancerous lesions [3]. One of the severe late consequences of chagasic megaesophagus is the increased risk ( $3 \%$ to $8 \%$ ) of developing esophageal squamous cell carcinoma (ESCC) compared to when megaesophagus is not present [4-6]. Also, ESCC develops in chagasic megaesophagus patients at a younger age than in those without this disease [5]. The detection of cancer in these patients is difficult because the symptoms are hidden by the severe dysphagia caused by megaesophagus [7]. The diagnosis is frequently late, when the patient is in advanced stage, resulting in a poor prognosis [5]. 
ESCC has been reported as the ninth most common malignancy and ranks the sixth most frequent cause of death worldwide, but its incidence varies largely among regions [8]. Approximately 16,470 new cases of esophageal carcinoma were expected in the US population in 2009 [9]. The Brazilian National Institute of Research in Cancer (INCA) reported that esophageal cancer was the sixth in the cancer rank mortality in 2000 with 5,307 deaths. The estimated incidence in 2008 was 10550 new cases with an incidence per 100 thousand individuals varying among geographical areas from 1.04 to 19.07 in males and 0.39 to 7.58 in females [8].

In ESCC, molecular cytogenetic techniques have shown common occurrence of unbalanced genomic regions involved in amplification of oncogenes and deletion of tumor suppressor genes $[10,11]$. However, studies in benign esophageal lesions with precancerous potential as megaesophagus are scarce. This study used FISH technique to investigate chagasic megaesophagus for genomic status of genes frequently unbalanced in ESCC with the goal of identifying potential markers of risk to cancer. The selected targets included FHIT, TP63, PIK3CA, EGFR, FGFR1, MYC, CDKN2A, YES1 and $N C O A 3$ genes, all of which have been reported as occurring in significantly abnormal numbers in ESCC [12-19].

\section{Methods}

\section{Subjects}

Formalin-fixed, paraffin-embedded (FFPE) esophageal mucosa was obtained from 40 patients with diagnosis of chagasic megaesophagus (CM) who underwent middle and distal esophageal biopsies from 2000 to 2007 at the Hospital de Base (São José do Rio Preto, SP, Brazil). The study was approved by the Institution Research Ethical Committee (CEP) and by the Brazilian National Research Ethics Committee (CONEP), and written informed consent was obtained from all patients. Among the $40 \mathrm{CM}$ patients, the mean age was 62.5 years (range: 40 - 83 years) and 20 were male; 29 were never-alcoholics, 3 former-alcoholics ( $\geq 5$ years of abstinence) and 8 current alcoholics; 18 were never-smokers, 6 former-smokers ( $\geq 5$ years of quitting) and 16 were current smokers. The megaesophagus diagnosis was made by physical examination, and radiologic and endoscopic study of esophageal motility by manometry [3]. The dilation grade of megaesophagus was classified as I to IV, based on the retention of contrast, diameter, tonicity of the lower sphincter and the length of the esophagus body [20]. This study cohort included 5 patients with megaesophagus grade I, 7 with grade II, 17 with grade III and 11 with grade IV. The CM group was followed for 2 to 4 years (median follow up $=2,8$ years) and no one developed ESCC, probably due to the short follow up of patients.

The control group (NM) was composed by 10 health subjects who were submitted to endoscopy under suspicion of dyspepsia, but the histopathological analysis has shown normal esophageal mucosa. In this group, the mean age was 42.4 (range: 26 - 67 years); 3 individuals were male and 7 female; 6 were never-alcoholics and four current alcoholics; 7 were never smokers and 3 current smokers.

\section{Fluorescence In Situ Hybridization (FISH)}

Serial $4 \mu \mathrm{m}$-thick sections were cut from paraffinembedded blocks and mounted in glass slides pre-treated with 3-aminopropyl-triethoxysilane/acetone solution. Specimens were incubated at $56^{\circ} \mathrm{C}$ overnight, deparaffinized in Citrisolv washes (Fisher Brand, Cat \#22143975) (three times for $10 \mathrm{~min}$ each), and dehydrated in $100 \%$ ethanol. After incubation in $2 \times \mathrm{SSC}$ (Sodium chloride, sodium citrate solution, $\mathrm{pH} 7.0)$ at $75^{\circ} \mathrm{C}$, sections were digested with proteinase $\mathrm{K}(0.25 \mathrm{mg} / \mathrm{ml}$ in 2 $\times \mathrm{SSC}, \mathrm{pH} 7.0)$ at $45^{\circ} \mathrm{C}$, rinsed in $2 \times \mathrm{SSC}(\mathrm{pH} \mathrm{7.0)}$ at room temperature for $5 \mathrm{~min}$ and dehydrated in an ethanol series.

The following DNA probe sets were used: (a) EGFR/ CEP7 (Abbott Molecular, Cat. \# 32-191053, EGFR mapped at 7p12), P16/CEP9 (Abbott Molecular, Cat. \# 32-190078, CDKN2A mapped at 9p12), c-MYC (Abbott Molecular, Cat. \# 32-190006, MYC mapped at 8q24)/ homebrew FGFR1 (RP11-350N15, mapped at 8p12), and the homebrew probes FHIT (CTD-2196D15, mapped at 3p14.2)/centromere 3 (p $\alpha$ 3.5), TP63 (RP11-373I6, mapped at 3q28)/PIK3CA (RP11-245C23, mapped at 3q26) and YES1 (RP11-769O8, mapped at 18q11.31)/ NCOA3 (RP11-456N23, mapped at 20q12). The homebrew probes were prepared from BAC clones and purified DNA was labeled using the Nick Translation Kit (Abbott Molecular Cat. \# 32-801300). In each probe set, one target was labeled with green fluorophore (Spectrum Green) and the other with red fluorophore (Spectrum Red). The probe set was applied to the selected area, which was covered with glass coverslip and sealed with rubber cement. Co-denaturation of chromosomal and probe DNAs was performed at $85^{\circ} \mathrm{C}$ for $10 \mathrm{~min}$ and hybridization was allowed to occur in a humidified chamber at $37^{\circ} \mathrm{C}$ for $20-24 \mathrm{~h}$ for commercial probes and 40-48 $\mathrm{h}$ for homebrew probes. After hybridization, the slides were washed twice in $2 \times \mathrm{SSC} / 0.3 \% \mathrm{NP}-40$ at $73^{\circ}$ $\mathrm{C}$ for $2 \mathrm{~min}$, rinsed in $2 \times \mathrm{SSC}$ at room temperature for 2 min, dehydrated in ethanol series, air dried and counterstained with 4', 6'-diamino-2-phenylindole - DAPI, $(0.3 \mathrm{ug} / \mathrm{ml}$ in Vectashield Mounting Medium, Vector, Cat. \# H-1200). 
Fluorescence signals were scored in epifluorescence microscope using single band filters for DAPI, FITC (fluorescein), and Texas red, double-band pass filter (FITC and Texas red) and triple-band pass filter (DAPI, FITC, and Texas Red). Histological areas previously selected in the HE-stained (hematoxylin and eosin) sections were identified in the hybridized slides. Signals were scored in 100 epithelial nuclei per specimen, in at least four distinct areas: 50 nuclei in the superficial layer (larger cells, closer to the lumen) and 50 nuclei in the basal layer (darker HE-stained nuclei, smaller cells, closer to the muscular layer). The scoring was performed in both layers to check for differences between proliferate activity, since basal layer cells are in high proliferative activity, whereas the superficial layer cells are more mature. For 3 genes, FHIT, EGFR and CDKN2A, the experiments were performed including centromeric sequences of carrier chromosomes as an internal control, respectively chromosomes 3,7 and 9 . This design was necessary for FHIT and CDKN2A since these genes are known for their loss in cancer specimens [21,22]. For each FISH probe set, tissue sections from two normal subjects were used as control.

\section{Statistical Analysis}

Descriptive statistics were calculated using an Microsoft Excel macro template previously validated including mean copy number per cell, standard deviation and frequency of cells with 1,2 and $\geq 3$ copies of each DNA target tested, as well as the ratio for gene/control probe when applicable. The superficial and basal layers were compared by $t$-student paired test, and between the experimental groups were compared by $t$-student unpaired test; in both cases confidence level was established as 0.05 [23]. Association between gene status with age, gender, life style factors (smoking and alcoholism), and megaesophagus grade in the CM group was compared by ANOVA and the comparisons for losses and gains, and aneusomies, between the groups, were done by $\chi^{2}$ test. One exploratory analysis using three-dimensional plots was performed for the percentages of genes status classes.

\section{Results}

The descriptive indexes (mean and standard deviation) for the tested genes (FHIT, PIK3CA, TP63, EGFR, FGFR1, MYC, CDKN2A, YES1, NCOA3) and centromeric sequences (chromosomes 3, 7 and 9 evaluated respectively with the genes FHIT, EGFR and CDKN2A), and the results of the statistical analyses for comparison of mean copy numbers between the superficial and basal layers in each group are presented in Table 1 . The mean values in the CM group ranged from 1.49 to 1.78 in the superficial layer and from 1.45 to 1.79 in the basal layer. In the NM group, the mean frequencies ranged from 1.35 to 1.77 in the superficial layer and from 1.61 to 1.79 in the basal layer. Superficial and basal layers of the esophageal mucosa did not show significant differences, excepted for EGFR in the CM group ( $\mathrm{p}=$ 0.008 ) that showed lower copy number in the basal layer. Results from both layers were combined for comparison of mean copy numbers per cell of the each molecular target and no difference was detected between CM and NM. However, the copy number of $C D K N 2 A$ was significantly lower $(\mathrm{p}<0.0001)$ in the $\mathrm{CM}$ group compared to $\mathrm{NM}$, and similar results were observed for the corresponding centromere 9 (CEP9) $(\mathrm{p}=0.0002)$.

In another investigative approach, frequencies of nuclei with normal ( 2 copies) or loss $(<2$ copies) and gain ( $>2$ copies) for each gene were compared (Table 2 ), and only for PIK3CA there were higher frequencies of cells with copy number loss in the CM group compared to NM (36.4\% vs. $28.5 \%)$. Statistical analysis was not performed for gain due to the scarcity of cells with this pattern. Aneusomies involving centromeres of chromosomes 3,7 , and 9 were also investigated (Table 2). The CM group showed significantly increased frequencies of cells with copy number loss of centromeres of chromosomes 7 and 9 (51\% and 44\%, respectively) in comparison to the NM group ( $28 \%$ and $23 \%$, respectively). The CM group also showed numerically higher frequencies of cells with copy number gain of centromeres of chromosomes 7 and 9 (1.68\% and $10.38 \%$, respectively) than the NM group ( $0.50 \%$ and none, respectively), although the numbers were too small for statistical analyses.

The gene/centromere ratios for FHIT/CEN3, EGFR/ CEP7 and CDKN2A/CEP9, the probe sets including matched targets in the study, were all balanced (close to 1 ) and differences were not detected between the mean copy number of each target within each group (Table 3). These results suggest that loss of FHIT, EGFR and CDKN2A was accompanied by loss of their respective chromosomes.

Data were also subject to an exploratory analysis using three-dimensional plots of the percentages of cells per genomic pattern (loss, balanced and gain) for individual cases as illustrated in Figure 1. Several cases were identified harboring deletions on specifics targets: $C M 7$ (YES1), CM12 (CDKN2A), CM13 (PIK3CA; TP63), CM19 (PIK3CA), CM30 (EGFR), CM36 (FHIT; CEP9), CM16 and CM34 (CEP9). Other cases showed genomic gain for specific targets: CM3 (MYC), CM6 (TP63; MYC), CM7 (TP63), CM11 (PIK3CA; CDKN2A), CM16 (CDKN2A), CM28 (PIK3CA), CM30 (MYC; FGFR1), CM36 (NCOA3), and CM11 and CM21 (CEP9). Figure 2 illustrates unbalanced status of genes and centromeric DNA targets in megaesophagus specimens. 
Table 1 Mean copy number per cell for the 12 DNA targets tested in esophageal mucosa of chagasic megaesophagus and normal mucosa groups.

\begin{tabular}{|c|c|c|c|c|c|c|c|}
\hline \multirow{4}{*}{ Targets } & \multicolumn{3}{|c|}{ CM } & \multicolumn{3}{|c|}{ NM } & \multirow{4}{*}{$\begin{array}{l}t \text {-Student } \\
\mathrm{CM} \times \mathrm{NN}\end{array}$} \\
\hline & \multicolumn{2}{|c|}{ Mucosa Layers } & & \multicolumn{2}{|c|}{ Mucosa Layers } & \multirow[b]{2}{*}{ Total } & \\
\hline & Superficial & Basal & Total & Superficial & Basal & & \\
\hline & \multicolumn{3}{|c|}{ Mean \pm SD } & \multicolumn{3}{|c|}{ Mean \pm SD } & \\
\hline \multirow[t]{2}{*}{$\overline{F H I T}$} & $1.77 \pm 0.08$ & $1.78 \pm 0.08$ & $1.76 \pm 0.08$ & $1.35 \pm 0.49$ & $1.75 \pm 0.04$ & $1.74 \pm 0.04$ & ${ }^{n s} P=0.7803$ \\
\hline & \multicolumn{3}{|c|}{ Range: 1.56-1.90 } & \multicolumn{3}{|c|}{ Range: $1.71-1.77$} & \\
\hline \multirow[t]{2}{*}{ PIK3CA } & $1.76 \pm 0.09$ & $1.78 \pm 0.08$ & $1.77 \pm 0.07$ & $1.70 \pm 0.09$ & $1.78 \pm 0.11$ & $1.74 \pm 0.01$ & ${ }^{n s} P=0.6982$ \\
\hline & \multicolumn{3}{|c|}{ Range: 1.56-1.96 } & \multicolumn{3}{|c|}{ Range: 1.64-1.86 } & \\
\hline \multirow[t]{2}{*}{ TP63 } & $1.77 \pm 0.11$ & $1.78 \pm 0.09$ & $1.77 \pm 0.09$ & $1.70 \pm 0.09$ & $1.78 \pm 0.11$ & $1.74 \pm 0.01$ & ${ }^{n s} P=0.5304$ \\
\hline & \multicolumn{3}{|c|}{ Range: 1.56-2.06 } & \multicolumn{3}{|c|}{ Range: $1.64-1.86$} & \\
\hline \multirow[t]{2}{*}{ EGFR } & $1.52 \pm 0.12^{\mathrm{a}}$ & $1.45 \pm 0.15^{b}$ & $1.49 \pm 0.13^{a, b}$ & $1.60 \pm 0.00$ & $1.74 \pm 0.01$ & $1.67 \pm 0.01$ & ${ }^{n s} p=0.3700$ \\
\hline & \multicolumn{3}{|c|}{ Range: $1.25-1.80$} & \multicolumn{3}{|c|}{ Range: $1.60-1.75$} & \\
\hline \multirow[t]{2}{*}{ FGFR1 } & $1.78 \pm 0.01$ & $1.76 \pm 0.10$ & $1.77 \pm 0.08$ & $1.63 \pm 0.01$ & $1.70 \pm 0.03$ & $1.67 \pm 0.03$ & ${ }^{n s} P=0.2200$ \\
\hline & \multicolumn{3}{|c|}{ Range: $1.56-2.22$} & \multicolumn{3}{|c|}{ Range: $1.62-1.72$} & \\
\hline \multirow[t]{2}{*}{ MYC } & $1.76 \pm 0.09$ & $1.75 \pm 0.09$ & $1.76 \pm 0.08$ & $1.66 \pm 0.01$ & $1.74 \pm 0.02$ & $1.70 \pm 0.01$ & ${ }^{n s} P=0.5396$ \\
\hline & \multicolumn{3}{|c|}{ Range: $1.58-1.77$} & \multicolumn{3}{|c|}{ Range: $1.69-1.70$} & \\
\hline \multirow[t]{2}{*}{ CDKN2A } & $1.49 \pm 0.08$ & $1.50 \pm 0.07$ & $1.50 \pm 0.06$ & $1.76 \pm 0.14$ & $1.72 \pm 0.01$ & $1.74 \pm 0.07$ & ${ }^{*} P<0.0001$ \\
\hline & \multicolumn{3}{|c|}{ Range: 1.34-1.59 } & \multicolumn{3}{|c|}{ Range: 1.69-1.79 } & \\
\hline \multirow[t]{2}{*}{ YES1 } & $1.67 \pm 0.13$ & $1.67 \pm 0.12$ & $1.67 \pm 0.11$ & $1.70 \pm 0.08$ & $1.68 \pm 0.13$ & $1.69 \pm 0.07$ & ${ }^{n s} P=0.8099$ \\
\hline & & Range: 1.3 & & & Range: $1.58-$ & & \\
\hline NCOA3 & $1.65 \pm 0.11$ & $1.64 \pm 0.11$ & $1.64 \pm 0.10$ & $1.66 \pm 0.11$ & $1.61 \pm 0.01$ & $1.64 \pm 0.06$ & ${ }^{n s} P=0.7656$ \\
\hline & & Range: 1.3 & & & Range: $1.59-$ & & \\
\hline Centromere 3 & $1.77 \pm 0.08$ & $1.79 \pm 0.07$ & $1.77 \pm 0.07$ & $1.71 \pm 0.07$ & $1.76 \pm 0.08$ & $1.74 \pm 0.08$ & ${ }^{n s} P=0.6638$ \\
\hline & & Range: 1.5 & & & Range: 1.68- & & \\
\hline Centromere 7 & $1.53 \pm 0.12$ & $1.50 \pm 0.16$ & $1.52 \pm 0.13$ & $1.67 \pm 0.01$ & $1.79 \pm 0.04$ & $1.73 \pm 0.21$ & ${ }^{n s} P=0.1235$ \\
\hline & & Range: 1.2 & & & Range: $1.76-$ & & \\
\hline Centromere 9 & $1.53 \pm 0.09$ & $1.53 \pm 0.09$ & $1.53 \pm 0.07$ & $1.77 \pm 0.15$ & $1.77 \pm 0.04$ & $1.77 \pm 0.10$ & ${ }^{*} P=0.0002$ \\
\hline & & Range: 1.3 & & & Range: $1.70-$ & & \\
\hline
\end{tabular}

$\mathrm{CM}$, chagasic megaesophagus; NM, normal mucosa; SD, standard-deviation; Statistical Analysis: $t$-Student; ${ }^{*}, \mathrm{P}<0.05 ;{ }^{\mathrm{ns}}, \mathrm{P}>0.05 ;{ }^{\mathrm{a}, \mathrm{b}}, \mathrm{P}=0.008$.

No significant association was detected in CM group between mean copy number per cell of each DNA target tested and parameters such as age, gender and the life style factors tobacco smoking and alcoholism although the small size of each subset impaired robust conclusion. Similarly, no significant differences were observed on mean copy number per cell of each genomic target according the dilation grades of megaesophagus (data not shown). However, the CM cases identified with genomics deletions and gains in the three-dimensional plots were mostly classified as grades III and IV, suggesting that chromosomal imbalances are more likely to occur in more advanced grades.

\section{Discussion}

Esophageal squamous cell carcinoma is one of the most prevalent cancers worldwide and has multifactorial origin, in which environment factors, especially alcohol ingestion and smoking, play significant role $[10,24]$. Several genetic alterations are also associated with ESCC, such as chromosomal changes, allelic deletions, activation of oncogenes and inactivation of tumor suppressor genes $[10,11]$. In tropical and subtropical countries of Latin America such as Brazil, the risk of ESCC may also be related to megaesophagus due to Chagas' disease. The period between onset of symptoms related to achalasia and detection of cancer ranges from 17 to 28 years [4]. In the current study no patient developed esophageal carcinoma, which can also be due to insufficient follow up.

This study showed that genomic copy number changes were not common events in megaesophagus. Among the tested 12 DNA targets mapped to 6 distinct chromosomes, there was only marginal differences between specimens from chagasic megaesophagus and normal esophageal mucosa. The only statistically significant difference in copy number between groups involved $C D K N 2 A$. Loss of function of CDKN2A (also called MTS-1 or P16) prevents the blocking of G1 phase and appears to be a necessary event for the progression of 
Table 2 Frequencies of cells with loss, normal status and gain in copy numbers of the target in chagasic megaesophagus and normal mucosa groups.

\begin{tabular}{|c|c|c|c|c|c|c|c|}
\hline \multirow[b]{2}{*}{ Target } & \multicolumn{3}{|c|}{$<2$ copies per cell } & \multicolumn{2}{|c|}{$\begin{array}{c}2 \text { copies per } \\
\text { cell }\end{array}$} & \multicolumn{2}{|c|}{$\begin{array}{c}>2 \text { copies per } \\
\text { cell }\end{array}$} \\
\hline & $\overline{C M}$ & NM & $\chi^{2}$ test & CM & NM & CM & NM \\
\hline \multicolumn{8}{|l|}{$\overline{F H I T}$} \\
\hline N & 20 & 2 & $P=10.672^{\mathrm{ns}}$ & 2478 & 144 & 6 & 3 \\
\hline$\%$ & 0.79 & 1.34 & & 98.96 & 96.64 & 0.24 & 2.04 \\
\hline \multicolumn{8}{|l|}{ PIK3CA } \\
\hline $\mathrm{N}$ & 898 & 57 & $P=0.000^{*}$ & 1530 & 139 & 35 & 4 \\
\hline$\%$ & 36.39 & 28.50 & & 61.99 & 69.50 & 1.42 & 2.00 \\
\hline \multicolumn{8}{|l|}{ TP63 } \\
\hline $\mathrm{N}$ & 885 & 58 & $P=2.579^{\text {ns }}$ & 2878 & 136 & 37 & 6 \\
\hline$\%$ & 23.29 & 29.00 & & 75.74 & 68.00 & 0.97 & 3.00 \\
\hline \multicolumn{8}{|l|}{ EGFR } \\
\hline N & 298 & 12 & $P=1.067^{\mathrm{ns}}$ & 3433 & 187 & 171 & 1 \\
\hline$\%$ & 7.59 & 6.00 & & 88.03 & 93.50 & 4.38 & 0.50 \\
\hline \multicolumn{8}{|l|}{ FGFR1 } \\
\hline N & 928 & 68 & $P=4.172^{\mathrm{ns}}$ & 2833 & 121 & 46 & 1 \\
\hline$\%$ & 24.38 & 34.00 & & 74.41 & 60.50 & 1.21 & 0.50 \\
\hline \multicolumn{8}{|l|}{ MYC } \\
\hline $\mathrm{N}$ & 918 & 62 & $P=4.812^{n s}$ & 2849 & 135 & 33 & 2 \\
\hline$\%$ & 24.00 & 31 & & 75.00 & 67.50 & 0.01 & 1.00 \\
\hline \multicolumn{8}{|l|}{ CDKN2A } \\
\hline N & 183 & 6 & $P=17.702^{n s}$ & 3649 & 194 & 68 & 0 \\
\hline$\%$ & 4.69 & 3.00 & & 93.56 & 97.00 & 1.74 & 0.00 \\
\hline \multicolumn{8}{|l|}{ YES1 } \\
\hline $\mathrm{N}$ & 1381 & 62 & $P=2.171^{\mathrm{ns}}$ & 2407 & 136 & 12 & 2 \\
\hline$\%$ & 36.34 & 31.00 & & 63.34 & 68.00 & 0.32 & 1.00 \\
\hline \multicolumn{8}{|l|}{ NCOA3 } \\
\hline N & 45 & 8 & $P=3.627^{n s}$ & 2366 & 130 & 8 & 0 \\
\hline$\%$ & 1.86 & 5.80 & & 97.81 & 94.20 & 0.33 & 0.00 \\
\hline \multicolumn{8}{|l|}{ CEN3 } \\
\hline N & 683 & 54 & $P=0.470^{n s}$ & 2510 & 145 & 7 & 1 \\
\hline$\%$ & 21.0 & 27.0 & & 78.44 & 72.5 & 0.56 & 0.50 \\
\hline \multicolumn{8}{|l|}{ CEP7 } \\
\hline N & 1637 & 56 & $P=0.00+^{*}$ & 1509 & 1143 & 54 & 1 \\
\hline$\%$ & 51.16 & 28.0 & & 47.16 & 71.50 & 1.68 & 0.50 \\
\hline \multicolumn{8}{|l|}{ CEP9 } \\
\hline $\mathrm{N}$ & 1400 & 46 & $P=0.00+^{*}$ & 1468 & 154 & 332 & 0 \\
\hline$\%$ & 43.75 & 23.0 & & 45.87 & 77.0 & 10.38 & 0.00 \\
\hline
\end{tabular}

CM, chagasic megaesophagus; NM, normal mucosa; SD, standard-deviation; Statistical Analysis: $t$-Student; ${ }^{*}, \mathrm{P}<0.05 ;{ }^{\mathrm{ns}}, \mathrm{P}>0.05 ;{ }^{\mathrm{a}, \mathrm{b}}, \mathrm{P}=0.008$.

pre-cancerous cells to malignancy [25,26]. Genetic and epigenetic alterations in CDKN2A have been reported in early stages of esophageal carcinogenesis [27-30]. In primary esophageal carcinomas and cell lines, deletions and point mutations in CDKN2A gene have been reported in $16 \%$ to $82 \%$ of cases [22,31], and hypermethylation of promoter region in $20 \%$ to $88 \%$ of ESCC and precancerous lesions [30,32]. The current study detected deletion of CDKN2A and CEP 9 sequences in
Table 3 Comparison between matched gene and centromere targets, in chagasic megaesophagus and normal mucosa groups.

\begin{tabular}{|c|c|c|c|c|c|}
\hline \multicolumn{2}{|c|}{ Gene-Centromere } & \multicolumn{2}{|c|}{$\mathrm{CM}$} & \multicolumn{2}{|l|}{ NM } \\
\hline & & Mean \pm SD & Ratio & Mean \pm SD & Ratio \\
\hline FHIT & & $1.77 \pm 0.08$ & 1.00 & $1.74 \pm 0.04$ & 1.00 \\
\hline \multirow[t]{2}{*}{ CEN3 } & & $1.77 \pm 0.08$ & & $1.74 \pm 0.08$ & \\
\hline & t-Student & ns & & ns & \\
\hline$E G F R$ & & $1.49 \pm 0.12$ & 0.98 & $1.67 \pm 0.01$ & 0.96 \\
\hline \multirow[t]{2}{*}{ CEP7 } & & $1.51 \pm 0.13$ & & $1.73 \pm 0.02$ & \\
\hline & t-Student & ns & & ns & \\
\hline CDKN2A & & $1.51 \pm 0.09$ & 1.00 & $1.74 \pm 0.07$ & 0.98 \\
\hline \multirow[t]{2}{*}{ CEP9 } & & $1.54 \pm 0.10$ & & $1.77 \pm 0.10$ & \\
\hline & t-Student & ns & & ns & \\
\hline
\end{tabular}

Chagasic megaesophagus, CM; normal mucosa, NM; SD, standard-deviation; Statistical Analysis: $t$-Student $n s, p>0.05$.

CM compared with NM group. In agreement with these findings, patients with idiopathic achalasia and chagasic megaesophagus, with or without esophageal carcinoma, showed reductions in expression of p16 protein [7] and Bellini et al. [33] observed a marginal decrease in p16 protein expression in chagasic megaesophagus. Additionally, recent subset analyses by our group did not find mutations in CDKN2A (exons 1 and 2) and FHIT (exons 5 and 7) genes, suggesting these events are uncommon in CM [34], and have detected copy number changes of chromosomes 7,11 and 17 and TP53 deletion by FISH [35].

The tumor suppressor gene FHIT (3p14.2) is deregulated during the development of ESCC. Deletion in both FHIT alleles results in failure in the transcript [36] and consequent absence or reduction of Fhit protein, which act in the cell cycle regulation and apoptosis. Genetic and epigenetic alterations of FHIT are associated with development of several cancer types [37,38]. Loss of heterozygosity (LOH) in areas of the 3p14-p21 bands has also been reported in low-grade dysplasia and postulated as early events in esophageal carcinogenesis [39]. While hypermethylation of FHIT gene has been described in $33 \%$ to $69.4 \%$ of ESCC cases, it is also known that deletion and loss of protein expression are frequent in esophageal carcinoma [32,36]. Deletion of FHIT observed in a single megaesophagus specimen in the present study may associate with early onset of genetic chances in these lesions, but it is worth to note that no significant decrease in the level of Fhit protein expression have been detected in chagasic megaesophagus [33].

All other tested genes are categorized as oncogenes and have been previously shown to associate with ESCC, in which they are commonly amplified [12-19]. However, abnormal copy number patterns were only seen in few individuals in the Chagasic megasophagus 

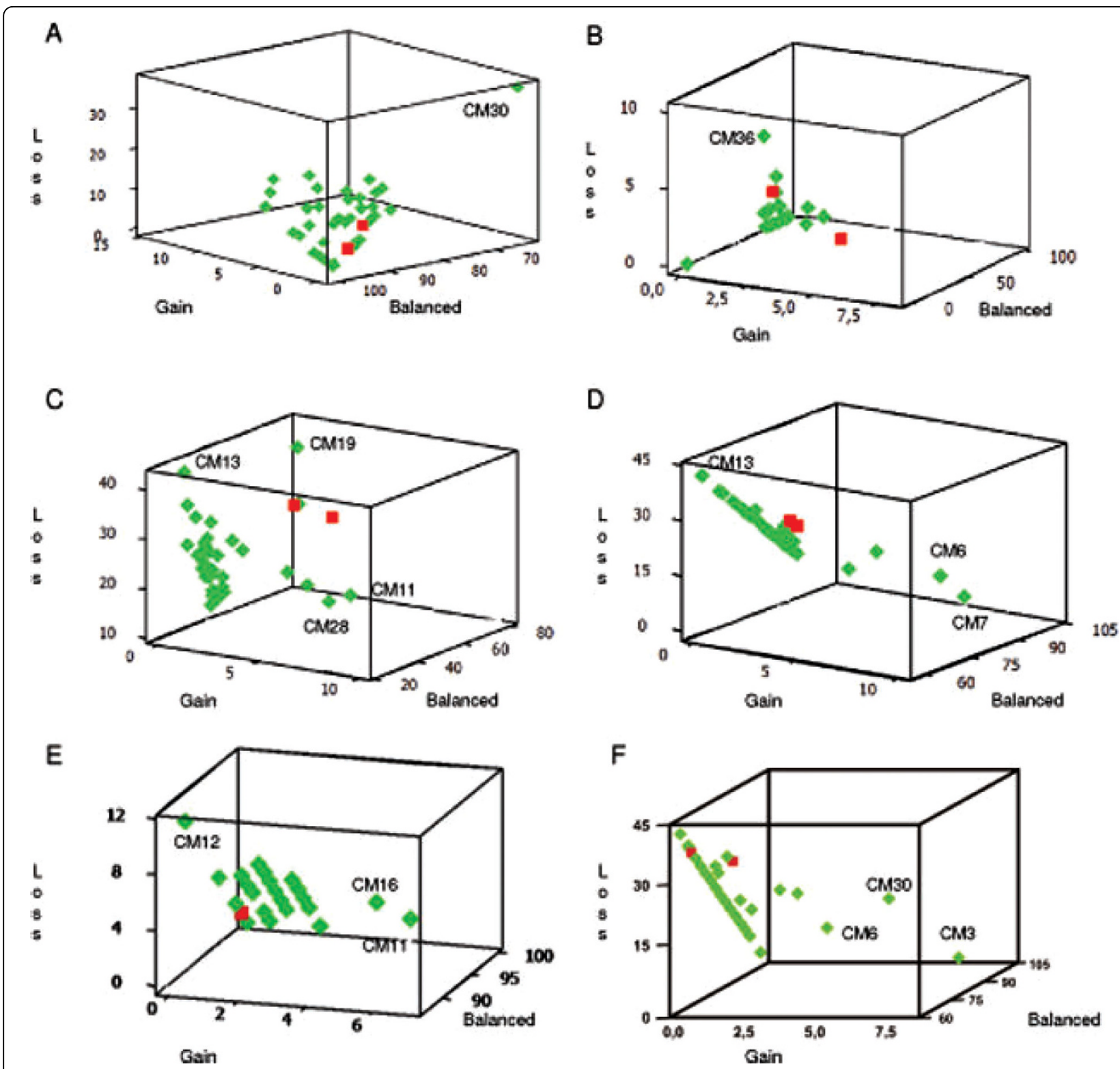

Figure 1 Exploratory analysis using three-dimensional plots of the percentages of genes status for individual cases is illustrated. Red square: Normal Mucosa; Green Square: Megaesophagus, A. EGFR, Mean frequency of loss in the CM =6.84\%, CM30 30\% of loss; B. FHIT, Mean frequency of loss in the CM $=0.63 \%$, CM36 10\% of loss; C. PIK3CA, Mean frequency of loss: $23.63 \%$, Mean frequency of gain: $0.92 \%$, CM 13 and CM19 40\% of loss, CM28 and CM11, between 5 and 10\% of gain; D. TP63, Mean frequency of loss $=23.29 \%$, Mean frequency of gain $=1.07 \%$, CM13 45\% of loss, CM6 and CM7 10\% of gain; E. CDKN2A, Mean frequency of loss $=4.76 \%$, Mean frequency of gain $=1.79 \%, C M 12 \sim 12 \%$ of loss, CM 11 and CM $16 \sim 6 \%$ of gain; F. MYC, Mean frequency of gain $=0.87 \%, C M 3, C M 6$ and CM30 between 5 and $7.5 \%$ of gain.

cohort and involved both gains and losses. One example is PIK3CA, which encodes the catalytic subunit that uses ATP to phosphorylate phosphatidylinositol, a gene that is frequently amplified in ESCC [40-42]. Yen et al. [40] determined in FISH assays that PIK3CA was amplified in cell lines and primary tumors and detected a positive correlation between amplification and tumor size, lymph node metastasis and clinical stage. Yang et al. [41] showed that PIK3CA gene amplification was highly correlated with protein overexpression, supporting amplification as a major mechanism for overexpression. Nevertheless, in this study PIK3CA was lost rather than amplified in the $\mathrm{CM}$ specimens as a group while involved in marginal level of loss two specimens and gained in two other specimens.

Gene amplification was one of the basic mechanisms leading to overexpression of the TP63 in ESCC $[18,43,44]$. The amplification of TP63, whose protein 

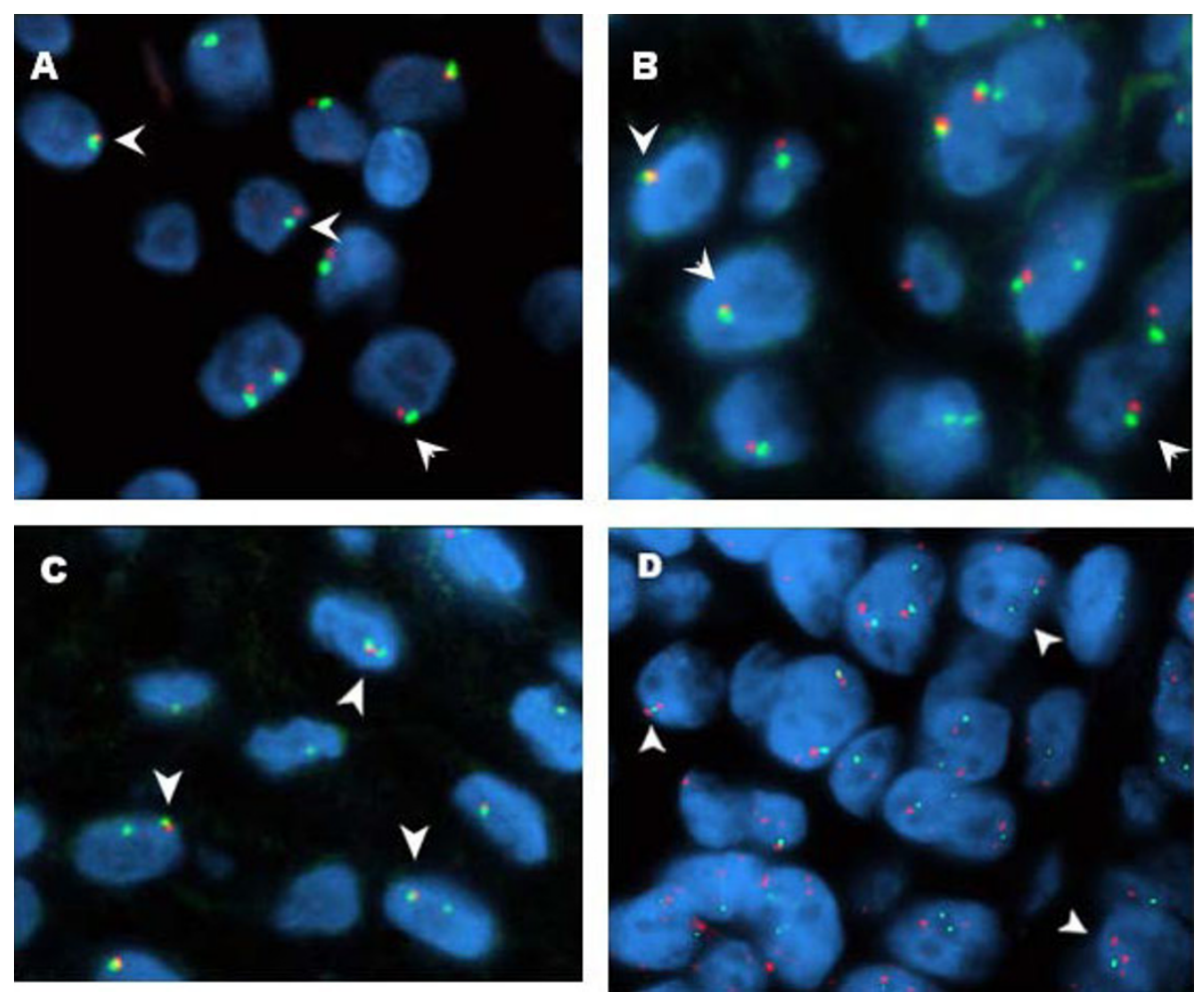

Figure 2 FISH images for the unbalanced genes and centromeric targets in the megaesophagus specimens. Dual-target, dual-color color hybridization in chagasic megaesophagus. A. Loss of CDKN2A (red signal) and centromere 9 (green signal); B. Loss of EGFR (red signal) and centromere 7 (green signal); C. Loss of FHIT (red signal) and centromere 3 (green signal); D. Gain of TP63 (red signal) and loss of PIK3CA (green signal). Arrows indicated cells with abnormal copy numbers of the genes.

plays in the development and maintenance of stratified epithelial tissues has been described in early stage of ESCC carcinogenesis but down-regulated in advanced $[18,43]$. Amplification of the membrane receptor genes EGFR and FGFR1 has been reported in various cancers including ESCC $[45,46]$, and this phenomenon has been suggested to be a poor prognostic factor in solid tumors [47]. In ESCC, co-expression of both aFGF and FGFR1 was associated with larger tumor area and worse prognosis which suggests that the membrane receptor may promote proliferation of esophageal cancer cells in an angiogenesis-independent and autocrine manner and may contribute to rapid recurrence after esophageal resection [47].

$M Y C$ is a transcription factor that binds E-boxes as a heterodimer with Max in about $15 \%$ of all genes, and recruits co-activators to regulate gene transcription. $M Y C$ is regulated in part through mitogenic stimuli and is activated constitutively in cancer cells through gene amplification, chromosomal translocation, point mutation and mitogenic stimulation [48]. MYC was found to be amplified in ESCC cell lines and in primary tumors [14]. YES1 codes a protein with tyrosine kinase activity that has been previously associated with esophageal carcinogenesis $[15,42]$. Similarly, the NCOA3 gene encoding a nuclear receptor coactivator that interacts with nuclear hormone receptors to enhance their transcriptional activator function was found frequently overexpressed and also amplified in 5 to $15 \%$ of ESCCs [49-51].

Although is well established that megaesophagus preferentially affects males between the second and fourth decades of life [3], this study has not detected relationship between copy numbers of each tested gene and parameters such as age, gender, life style factors (tobacco smoking and alcoholism) and megaesophagus grade in the CM group. Nevertheless these findings may have been impacted by the limited number of samples in each category.

Interestingly, specimens with genomics deletions and gains exhibited mostly more advanced dilation grades. Megaesophagus patients have high variety of esophageal microbiota, which consists mainly of Gram-positive anaerobic bacteria in concentrations that correlated with the degree of esophageal dilation [6,52]. Bacteria in fluid stasis can undergo reduction from nitrates to nitrites 
with the production of $\mathrm{N}$-nitrous compounds, which has potent action in esophageal carcinogenesis [52]. High grade megaesophagus present higher dilation and esophageal stasis associated with bacterial proliferation, thus the data suggest that the level of dilation and inflammation of megaesophagus could promote genetic damages and could be related to increased risk of tumor development $[4,7,53]$.

\section{Conclusion}

In conclusion, among 40 chagasic megaesophagus comprehensively investigated with a panel of FISH probes, copy number gain was only displayed by three specimens for $M Y C$, by one specimen for FGFR1 and one specimen for NCOA3. Loss of FHIT and YES1 was seen in one specimen and of $E G F R$ in another. For the remainder genes CDKN2A, PIK3CA and TP63, from one to four specimens each showed copy number gain or loss. In every case the difference was only marginal therefore not providing strong support to a biological impact. These findings show that imbalances involving the genomic regions encompassing gene sequences relevant in esophageal carcinogenesis were not found as significant events in chagasic megaesophagus. Consequently, genomic imbalances are not promising markers for assessment of ESCC risk in chagasic megaesophagus.

\section{List of abbreviations}

aFGF: endothelial cell growth factor, alpha; ANOVA: Analysis of Variance; BAC: Bacterial Artificial Chromosomes; Cat. \#: Catalog number; CDKN2A: cyclin-dependent kinase inhibitor 2A (melanoma, p16: inhibits CDK4); CEN3: Centromere 3; CEP: Research Ethical Committee; CEP7: Centromere 7; CEP9: Centromere 9; CM: patients with histologic diagnosis of chagasic megaesophagus; CONEP: Brazilian National Research Ethics Committee; DAPI: 4', 6'-diamino-2-phenylindole; EGFR: epidermal growth factor receptor [erythroblastic leukemia viral (v-erb-b) oncogene homolog, avian]); ESCC: Esophageal squamous cell carcinoma; FFPE: formalinfixed, paraffin-embedded; FGFR1: fibroblast growth factor receptor 1; FHIT: fragile histidine triad gene; FISH: Fluorescence In Situ Hybridization; FITC: fluorescein isothiocyanate; HE: Hematoxylin and Eosin stain; LOH: loss of heterozygosity; $M Y C: \mathrm{v}-\mathrm{myc}$ myelocytomatosis viral oncogene homolog (avian); NCOA3: nuclear receptor coactivator 3; NM: health individuals with histologically normal esophagus; PIK3CA: phosphoinositide-3kinase, catalytic, alpha polypeptide; Q-PCR: Quantitative - Polymerase Chain Reaction; SSC: Sodium chloride, sodium citrate solution; TP63: tumor protein p63; Vs: versus; YES1: v-yes-1 Yamaguchi sarcoma viral oncogene homolog 1.

\section{Acknowledgements}

The authors are grateful to Dr. Kenji Miyazaki and Henrique Oliveira for collecting the biopsies; Dr. Patricia Maluf Cury for providing the tissue blocks and pathology evaluation; Dr. Sebastião Roberto Taboga and Luiz Roberto Faleiros for help with histological sections. We also thank the Brazilian Agency CAPES and the NCl grants U01CA85070, P30-CA46934 and P50 CA58187 for financial and technical support.

\section{Author details}

${ }^{1}$ UNESP, São Paulo State University, Department of Biology, Campus São José do Rio Preto, SP, Brazil. ${ }^{2}$ University of Colorado Denver, Department of Medicine/Medical Oncology, Aurora, Colorado, USA. ${ }^{3}$ UNESP, São Paulo State University, Department of Computer Sciences and Statistics, Campus São José do Rio Preto, SP, Brazil.

\section{Authors' contributions}

MFB carried out the probe development, molecular cytogenetic studies and drafted the manuscript. AJM performed the statistical analysis. AES and MVG conceived the study, participated in its design and execution and contributed to the manuscript. All authors read and approved the final manuscript.

\section{Competing interests}

The authors declare that they have no competing interests.

Received: 21 July 2009

Accepted: 17 February 2010 Published: 17 February 2010

\section{References}

1. WHO, World Health Organization. http://www.who.int/neglected_diseases/ diseases/chagas/en/index.html.

2. Moncayo A, Silveira CA: Current epidemiological trends for Chagas disease in Latin America and future challenges in epidemiology, surveillance and health policy. Mem Inst Oswaldo Cruz 2009, 104(I):17-30

3. Kraichely RE, Farrugia G: Achalasia: physiology and etiopathogenesis. Dis Esophagus 2006, 19:213-223.

4. Bektas A, Yasa MH, Kuzu I, Dogan I, Unal S, Ormeci N: Flow Cytometric DNA analysis and immunohistochemical p53, PCNA and histopathologic study in primary achalasia: preliminary results. Hepatogastroenterology 2001, 48:408-412.

5. Brücher BLDM, Stein HJ, Bartels H, Feussner H, Siewert JR: Achalasia and esophageal cancer: incidence, prevalence and prognosis. World I Surg 2001, 25:745-749.

6. Gockel I, Kammerer P, Brieger J, Heinrich UR, Mann WJ, Bittinger F, Eckardt $V F$, Junginger T: Image cytometric DNA analysis of mucosal biopsies in patients with primary achalasia. World J Gastroenterol 2006 21:3020-3025.

7. Chino O, Kijima H, Shimada H, Nishi T, Tanaka H, Oshiba G, Kise Y, Kajiwara H, Tsuchida T, Tanaka M, Tajima T, Makuuchi H: Clinicopathological studies of esophageal carcinoma in achalasia: analysis of carcinogenesis using histological and immunohistochemical procedures. Anticancer Res 2000, 20:3717-3722.

8. INCA, Instituto Nacional do Câncer. http://www.inca.gov.br.

9. American Cancer Society. http://www.cancer.org/docroot/CRI/content/ CRI_2_2_1X_How_many_people_get_esophagus_cancer_12.asp?sitearea=

10. Kuwano H, Kato H, Miyazaki T, Fukuchi M, Masuda N, Nakajima M, Fukai Y, Sohda M, Kimura H, Faried A: Genetic alterations in esophageal cancer. Surg Today 2005, 35:7-18

11. D'Amico TA: Molecular biologic staging of esophageal cancer. Thorac Surg Clin 2006, 16(Suppl 4):31-327.

12. Pack SD, Karkera JD, Zhuang Z, Pak ED, Balan KV, Hwu P, Park WS, Pham T, Ault DO, Glaser M, Liotta L, Detera-Wadleigh SD, Wadleigh RG: Molecular cytogenetic fingerprinting of esophageal squamous cell carcinoma by comparative genomic hybridization reveals a consistent pattern of chromosomal alterations. Genes Chromosomes Cancer 1999, 25(2):160-168.

13. Yen CC, Chen YJ, Chen JT, Hsia JY, Chen PM, Liu JH, Fan FS, Chiou TJ, Wang WS, Lin CH: Comparative genomic hybridization of esophageal squamous cell carcinoma: correlations between chromosomal aberrations and disease progression/prognosis. Cancer 2001, 92(11):2769-2777. 
14. Ishizuka T, Tanabe C, Sakamoto H, Aoyagi K, Maekawa M, Matsukura N, Tokunaga A, Tajiri T, Yoshida T, Terada M, Sasaki H: Gene amplification profiling of esophageal squamous cell carcinomas by DNA array CGH. Biochem Biophys Res Commun 2002, 296(1):152-5.

15. Nakakuki K, Imoto I, Pimkhaokham A, Fukuda Y, Shimada Y, Imamura M, Amagasa T, Inazawa J: Novel targets for the 18p11.3 amplification frequently observed in esophageal squamous cell carcinomas. Carcinogenesis 2002, 23(1):19-24.

16. Arai H, Ueno T, Tangoku A, Yoshino S, Abe T, Kawauchi S, Oga A, Furuya T, Oka M, Sasaki K: Detection of amplified oncogenes by genome DNA microarrays in human primary esophageal squamous cell carcinoma: comparison with conventional comparative genomic hybridization analysis. Cancer Genet Cytogenet 2003, 146(1):16-21.

17. Shiomi H, Sugihara H, Kamitani S, Tokugawa T, Tsubosa Y, Okada K, Tamura H, Tani T, Kodama M, Hattori T: Cytogenetic heterogeneity and progression of esophageal squamous cell carcinoma. Cancer Genet Cytogenet 2003, 147(1):50-61.

18. Yen CC, Chen YJ, Pan CC, Lu KH, Chen PC, Hsia JY, Chen JT, Wu YC, Hsu WH, Wang LS, Huang MH, Huang BS, Hu CP, Chen PM, Lin CH: Copy number changes of target genes in chromosome 3q25.3-qter of esophageal squamous cell carcinoma: TP63 is amplified in early carcinogenesis but down-regulated as disease progressed. World J Gastroenterol 2005, 11(9):1267-1272.

19. Wang LD, Qin YR, Fan ZM, Kwong D, Guan XY, Tsao GS, Sham J, Li JL, Feng XS: Comparative genomic hybridization: comparison between esophageal squamous cell carcinoma and gastric cardia adenocarcinoma from a high-incidence area for both cancers in Henan, northern China. Dis Esophagus 2006, 19(6):459-67.

20. de Rezende J, Lauar KM, de Oliveira A: Clinical and radiological aspects of aperistalsis of the esophagus. Rev Bras Gastroenterol 1960, 12:247-262.

21. Pekarsky $Y$, Zanesi N, Palamarchuk A, Huebner K, Croce CM: FHIT: from gene discovery to cancer treatment and prevention. Lancet Oncol 2002, 3:748-54.

22. Chen PL, Cheng YW, Chiang CC, Tseng SH, Chau PS, Tsai YY: Hypermethylation of the p16 gene promoter in pterygia and its association with the expression of DNA methyltransferase 3b. Molecular Vision 2006, 12:1411-1416.

23. Graphpad. http://www.graphpad.com/instat

24. Pelucchi C, Gallus S, Garavello W, Bosetti C, La Vecchia C: Alcohol and tobacco use, and cancer risk for upper aerodigestive tract and liver. Eur J Cancer Prev 2008, 17(4):340-344.

25. Mori T, Miura K, Aoki T, Nishihira T, Mori S, Nakamura Y: Frequent somatic mutation of the MTS1/CDK4I (multiple tumor suppressor/cyclindependent kinase 4 inhibitor) gene in esophageal squamous cell carcinoma. Cancer Res 1994, 54:3396-3397.

26. Nuovo G, Plaia TW, Belinsky SA, Baylin SB, Herman JG: In situ detection of the hypermethylation-induced inactivation of the $p 16$ gene as an early event in oncogenesis. PNAS 1999, 96(22):12754-12759.

27. Kato H, Yoshikawa M, Fukai Y, Tajima K, Masuda N, Tsukada K, Kuwano H, Nakajima T: An immunohistochemical study of p16, pRb, p21 and p53 proteins in human esophageal cancers. Anticancer Res 2000, 20:345-349.

28. Chang MS, Lee HS, Lee BL, Kim YT, Lee JS, Kim WH: Differential protein expression between esophageal squamous cell carcinoma and dysplasia and prognostic significance of protein markers. Pathol Res Pract 2005, 201(Suppl 6):417-425.

29. Huang H, Wang LF, Tian HM, Liu Y, Li M, Qu P, Wang WR, Zhang W: Expression of retinoic acid receptor-beta mRNA and p16, p53, Ki67 proteins in esophageal carcinoma and its precursor lesions. Zhonghua Zhong Liu Za Zhi 2005, 27(3):152-5.

30. Fujiwara S, Noguchi T, Takeno S, Kimura Y, Fumoto S, Kawahara K Hypermethylation of $p 16$ gene promoter correlates with loss of $p 16$ expression that results in poorer prognosis in esophageal squamous cell carcinomas. Dis Esophagus 2008, 21:125-131.

31. Chen J, Guo L, Peiffer DA, Zhou L, Chan OT, Bibikova M, Wickham-Garcia E, Lu SH, Zhan Q, Wang-Rodriguez J, Jiang W, Fan JB: Genomic profiling of 766 cancer-related genes in archived esophageal normal and carcinoma tissues. Int J Cancer 2008, 122(10):2249-54.

32. Kim YT, Park JY, Jeon YK, Park SJ, Song JY, Kang CH, Sung SW, Kim JH: Aberrant promoter $\mathrm{CpG}$ island hypermethylation of the adenomatosis polyposis coli gene can serve as a good prognostic factor by affecting lymph node metastasis in squamous cell carcinoma of the esophagus. Dis Esophagus 2009, 22(2):143-50.

33. Bellini MF, Leite KRM, Cury PM, Silva AE: p53, p16 and Fhit proteins expressions in chronic esophagitis and chagas disease. Anticancer Res 2008, 28(Suppl 6B):3793-3799.

34. Manoel-Caetano FS, Silveira AFP, Silva AE: Gene mutations in esophageal mucosa of Chagas disease patients. Anticancer Res 2009, 29(Suppl 4):1243-1247.

35. Manoel-Caetano F, da S, Borim AA, Caetano A, Cury PM, Silva AE: Cytogenetic alterations in chagasic achalasia compared to esophageal carcinoma. Cancer Genet Cytogenet 2004, 149(1):17-22.

36. Druck T, Hadaczek P, Fu TB, Ohta M, Siprashvili Z, Baffa R, Negrini M, Kastury K, Veronese ML, Rosen D, Rothstein J, McCue P, Cotticelli MG, Inoue $\mathrm{H}$, Croce $\mathrm{CM}$, Huebner $\mathrm{K}$ : Structure and expression of the human FHIT gene in normal and tumor cells. Cancer Res 1997, 57:504-512.

37. Mori M, Mimori K, Shiraishi T, Alder $H$, Inoue $H$, Tanaka $Y$, Sugimachi $K$, Huebner K, Croce CM: Altered expression of Fhit in carcinoma and precarcinomatous lesions of the esophagus. Cancer Res 2000, 60:1177-1182.

38. Kuroki T, Trapasso F, Yendamuri S, Matsuyama A, Alder H, Mori M, Croce CM: Allele loss and promoter hypermethylation of VLH, RAR-beta, RASSF1A, and FHIT tumor suppressor genes on chromosome $3 p$ in esophageal squamous cell carcinoma. Cancer Res 2003, 63:3724-3728.

39. Roth MJ, Abnet CC, Hu N, Wang QH, Wei WQ, Green L, D'Alelio M, Qiao YL, Dawsey SM, Taylor PR, Woodson K: p16, MGMT, RARbeta2, CLDN3, CRBP and MT1G gene methylation in esohageal squamous cell carcinoma and its precursor lesions. Oncol Rep 2006, 15(6):1591-1597.

40. Yen CC, Chen YJ, Lu KH, Hsia JY, Chen JT, Hu CP, Chen PM, Liu JH, Chiou TJ, Wang WS, Yang MH, Chao TC, Lin CH: Genotypic analysis of esophageal squamous cell carcinoma by molecular cytogenetics and real-time quantitative polymerase chain reaction. Int J Oncol 2003, 23(4):871-881

41. Yang YL, Chu JY, Luo ML, Wu YP, Zhang Y, Feng YB, Shi ZZ, Xu X, Han YL, Cai Y, Dong JT, Zhan QM, Wu M, Wang MR: Amplification of PRKCl, located in 3q26, is associated with lymph node metastasis in esophageal squamous cell carcinoma. Genes Chromosomes Cancer 2008, 47(2):127-136.

42. NCBI, National Center for Biotechnology Information. http://www.ncbi nlm.nih.gov/sites/entrez.

43. Hibi K, Trink B, Patturajan M, Westra WH, Caballero OL, Hill DE, Ratovitski EA, Jen J, Sidransky D: AIS is an oncogene amplified in squamous cell carcinoma. Proc Natl Acad Sci USA 2000, 97(Suppl 10):5462-5467.

44. Hu H, Xia SH, Li AD, Xu X, Cai Y, Han YL, Wei F, Chen BS, Huang XP, Han YS, Zhang JW, Zhang X, Wu M, Wang MR: Elevated expression of p63 protein in human esophageal squamous cell carcinomas. Int J Cancer 2002, 102:580-583.

45. Sunpaweravong $P$, Sunpaweravong $S$, Puttawibul $P$, Mitarnun W, Zeng $C$, Barón AE, Franklin W, Said S, Varella-Garcia M: Epidermal growth factor receptor and cyclin D1 are independently amplified and overexpressed in esophageal squamous cell carcinoma. J Cancer Res Clin Oncol 2005, 131(2):111-119.

46. Hanawa M, Suzuki S, Dobashi Y, Yamane T, Kono K, Enomoto N, Ooi A: EGFR protein overexpression and gene amplification in squamous cell carcinomas of the esophagus. Int J Cancer 2006, 118(Suppl 5):1173-1180.

47. Sugiura K, Ozawa S, Kitagawa Y, Ueda M, Kitajima M: Co-expression of aFGF and FGFR-1 is predictive of a poor prognosis in patients with esophageal squamous cell carcinoma. Oncol Rep 2007, 17(3):557-564.

48. Adhikary S, Eilers M: Transcriptional regulation and transformation by Myc proteins. Nat Rev Mol Cell Biol 2005, 6:635-645.

49. Fujita Y, Sakakura C, Shimomura K, Nakanishi M, Yasuoka R, Aragane $H_{\text {, }}$ Hagiwara A, Abe T, Inazawa J, Yamagishi H: Chromosome arm 20q gains and other genomic alterations in esophageal squamous cell carcinoma, as analyzed by comparative genomic hybridization and fluorescence in situ hybridization. Hepatogastroenterol 2003, 50(Suppl 54):1857-1863.

50. Xu FP, Xie D, Wen JM, Wu HX, Liu YD, Bi J, Lv ZL, Zeng YX, Guan XY: SRC3/AIB1 protein and gene amplification levels in human esophageal squamous cell carcinomas. Cancer Lett 2007, 245(1-2):69-74.

51. Xu FP, Liu YH, Zhuang HG, Li L, Luo XL, Wen JM: Role of AIB1 gene in development of esophageal squamous cell carcinoma and its clinicopathologic significance. Zhonghua Bing Li Xue Za Zhi 2008, 37(4):250-254. 
52. Pajecki D, Zilberstein B, dos Santos MA, Ubriaco JA, Quintanilha AG,

Cecconello I, Gama-Rodrigues J: Megaesophagus Microbiota: A Qualitative and Quantitative Analysis. Journal of Gastrointestinal Surgery 2002, 6:723-729.

53. Lehman MB, Clark SB, Ormsby AH, Rice TW, Richter JE, Goldblum JR: Squamous mucosal alterations in esophagectomy specimens from patients with end-stage achalasia. Am J Surg Pathol 2001, 25:1413-1418.

Pre-publication history

The pre-publication history for this paper can be accessed here:http://www. biomedcentral.com/1471-230X/10/20/prepub

doi:10.1186/1471-230X-10-20

Cite this article as: Bellini et al:: Chromosomal imbalances are

uncommon in chagasic megaesophagus. BMC Gastroenterology 2010

10:20

Submit your next manuscript to BioMed Central and take full advantage of:

- Convenient online submission

- Thorough peer review

- No space constraints or color figure charges

- Immediate publication on acceptance

- Inclusion in PubMed, CAS, Scopus and Google Scholar

- Research which is freely available for redistribution

Submit your manuscript at www.biomedcentral.com/submit 